Vulnerable consumer engagement: How corporate social media can facilitate the replenishment of depleted resources

Judith Fletcher-Brown $^{\text {a }}$, Sarah Turnbull a , Giampaolo Viglia ${ }^{\mathrm{a}, *}$, Tom Chen ${ }^{\text {b,c }}$, Vijay Pereira ${ }^{\mathrm{d}}$

${ }^{a}$ University of Portsmouth, Department of Marketing, Richmond Building, Portland Street, PO13DE Portsmouth, UK

${ }^{\mathrm{b}}$ Canberra Business School, The University of Canberra, Bruce, Canberra, ACT 2617, Australia

${ }^{\mathrm{c}}$ Research School of Population Health, and Research School of Management, the Australian National University, Acton, ACT 2601, Australia

${ }^{\mathrm{d}}$ Khalifa University, Department of Humanities and Social Sciences, 127788 Abu Dhabi, United Arab Emirates 


\section{Vulnerable consumer engagement: How corporate social media can facilitate the replenishment of depleted resources.}

Technology may facilitate health and wellbeing consumer engagement. When there is scant public health provision and socio-cultural norms marginalise consumers stigmatised from cancer, we reveal how a brands' corporate social media campaign can support vulnerable consumers with resource constraints. Drawing from a transformative consumer research lens, we investigate five years of computer-mediated communications facilitated by the Indian brand Dabur Vatika. Through a grounded theory and an abductive reasoning approach, we unveil how vulnerable consumers directly or indirectly affected by cancer leverage brand's social media to replenish resources. First, we identify how vulnerable consumers engage to replenish depleted emotional and social support resources. We further expand consumer engagement scholarship by offering a preliminary definition of "vulnerable consumer engagement". Second, we provide a nascent classification of vulnerable consumers in a consumer-producer role, Principal Vulnerable Consumers and Associate Vulnerable

Consumers, distinguished by their proximity to the vulnerable context. Lastly, we reveal how brands may perform a transformative role, to replenish social, emotional and operant resources at micro level through the engagement of vulnerable consumers with corporate social media. This insight is informative for policymakers, advertising practitioners and transformative consumer research academics.

Keywords: corporate social media; vulnerable consumer engagement; cancer; stigma; depleted resources; technology. 


\section{Introduction}

Health and wellbeing education and support is normally created upstream with macro level health policy (Wallack et al., 1993; Wymer, 2011; Frow et al., 2016). However, when market contexts lack macro level public health support, consumers with resource constraints are rendered vulnerable (Pavia and Mason, 2014). From a transformative consumer research perspective, we explore how vulnerable consumers with resource constraints can be supported through engagement with a brand's corporate social media campaign (Anderson et al., 2013).

A vulnerable person is defined as, "an individual with the diminished capacity to anticipate, cope with, resist and recover from the impact of natural or human-made hazards" (IFRC, 2018). In a context where socio-cultural norms discourage cancer discourse and where depleted public health resources exist, cancer patients are positioned as vulnerable (Barg and Grier, 2008; Hollebeek and Chen, 2014). Health researchers have found cancer patients are often stigmatised within their community and suffer from a lack of emotional and social support (Yao, Zheng, and Fan, 2015). Furthermore, vulnerable consumers living with resource constraints experience limited prospects of early recuperation from illness because of inadequate health and wellbeing knowledge (Pounders and Mason, 2018).

Consumer engagement theorists highlight consumers may invest their cognitive resources to seek information from social media, but there is insufficient understanding about vulnerable consumer engagement with a brand in the digital space (Brennan et al., 2011; Hollebeek et al., 2014; Maslowska et al., 2016). Since its conceptualization in consumer, branding and services research, consumer engagement scholarship has grown in breadth 
(Brodie et al., 2011; Chen et al., 2020; Hollebeek and Chen, 2014; Hollebeek and Macky, 2019). Following in-depth examination of extant literature, consumer engagement is widely acknowledged to increase inter alia, brand loyalty, lifetime value, satisfaction, empowerment, connection, emotional bonding, trust and commitment (Gensler et al., 2013; Hollebeek, 2011; 2018; Kim et al., 2016; Verhoef et al., 2010; Verhoef et al., 2016). In this study, we adopt the notion of service dominant logic informed consumer engagement (Hollebeek et al., 2019, p.166) referred to as, “a consumer's motivationally driven, volitional investment of focal operant resources (including cognitive, emotional, behavioral, and social knowledge and skills), and operand resources (e.g., equipment) into brand interactions in service systems".

Importantly, Hollebeek et al. (2019) recognise consumer engagement benefits which refer to consumer individual operant resource development, consumer interpersonal operant resource development, and consumer co-creation. Such benefits can manifest through positive-valenced consumer engagement which can be perceived not only after, but also during interactions. Examples of positively-valenced consumer engagement are cognition, emotion or behavior that exhibit enthusiasm or other such heightened levels of goodwill towards the brand message (Hollebeek and Chen, 2014). Recognising consumer engagement benefits is particularly relevant to this study's context because in circumstances of poor macro level resource provision, evidence suggests vulnerable consumers usually suffer from depleted operant resources (knowledge about the disease) and limited operand resources (such as access to information pamphlets about cancer care) (Hollebeek et al., 2019).

In the development of the conceptualization of vulnerable consumer engagement it is important to understand the context of vulnerability that emanates from chronic disease such as cancer. The individual who is categorized as vulnerable is likely to engage in resources that offer support at a time of personal crisis and this may involve peers, family and friends. 
Leino $(2017$, p.761) in her work on care services for the elderly, labelled patients as 'primary customers' and granted family members the status of 'secondary customers', exposed to 'secondary vulnerability'. In the care services research scenario, 'secondary customers' sought emotional support and other resources from the care service providers, to reinforce their strength to cope. Drawing from past literature which highlights different vulnerability intensity (Leino, 2017; Pavia and Mason, 2014), we delineate two categories of vulnerable consumers who are immerse in a consumer-producer role, Principal Vulnerable Consumers and Associate Vulnerable Consumers, and we specifically focus on hair loss through cancer.

Principal Vulnerable Consumers are those directly affected by the chronic disease, while Associate Vulnerable Consumers have some proximity to the disease, e.g. by family or friendship connection. Principal Vulnerable Consumers and Associate Vulnerable Consumers engage in the co-creation process of an emotional and social resource network to replenish depleted supportive resources that are not provided by macro level health service organizations. This consumer-producer role is unusual and evidenced by their cognitive, emotional and behavioral engagement with the meso level corporate social media campaign. Consequently, these roles are significantly different to 'primary and secondary customers' who act as passive receivers of support resources provided by an existing customer care service context (Leino, 2017). Therefore, our investigation develops scholarship in the consumer engagement research domain.

This study makes three original contributions to consumer engagement research. First, while there is widespread acknowledgement of consumer engagement with social media campaigns (Loureiro and Lopes, 2019), to the best of our knowledge, there has been no examination of how a brand's corporate social media engages vulnerable consumers to enhance their wellbeing in a resource-depleted context. Specifically, we identify the key dimensions of how vulnerable consumers engage to replenish depleted emotional and 
social support resources and a knowledge hub that renders operant resources. In so doing, our work expands consumer engagement scholarship by offering a preliminary definition of, "vulnerable consumer engagement" (VCE) as, "the level of replenishment of depleted cognitive, emotional, behavioral and social resources invested by vulnerable individuals with scant operant resources" a topic that is still in its infancy with its nature and organizational scope not fully developed.

Second, we provide a nascent classification of vulnerable consumers, Principal Vulnerable Consumers and Associate Vulnerable Consumers, distinguished by their proximity to the vulnerable context. We reveal corporate social media facilitates Principal Vulnerable Consumer and Associate Vulnerable Consumer engagement to stimulate a consumer-producer role, which is unusual.

Third, we identify at meso level how a brands' computer-mediated communications may perform a transformative role, to replenish social, emotional and operant resources at micro level through the engagement of vulnerable consumers with corporate social media. Specifically, we illustrate how in an emerging country context, social, emotional and operant resources can be replenished at micro level through the engagement of Principal Vulnerable Consumers and Associate Vulnerable Consumers with a corporate social media campaign. This insight is valuable for policymakers, advertising practitioners and transformative consumer research academics.

The paper is structured as follows. We start by explaining the conceptual link between engagement and wellbeing through co-creation of value (Dietrich et al., 2017; Vargo and Lusch, 2016). Next, using abductive reasoning to expand the scope of understanding, we explore the VCE phenomenon without the constraints of ridged theoretical application (Belk and Sobh, 2019). Thereafter, a presentation of the analysis and we conclude with implications for theory and a rich agenda for future research. 


\section{The role of technology to engage vulnerable consumers with corporate social media campaigns}

Consumers are more frequently turning to online computer-mediated communication to support their choices. Techniques such as incorporating a co-creative design or a transformational message strategy have facilitated an increase in consumer participation levels (Tafesse and Wien, 2018). Although uniformly known as, "virtual communities", these social groups have a real existence for participants, with consequential effects on consumer behavior (Kozinets, 2002, p.366). Recent research has found that organisations who engage consumers in social media messages are more effective in creating awareness about their corporate societal cause (Loureiro and Lopes, 2019). In addition, brands that signal a genuine connection to a cause are usually perceived as trustworthy by consumers who are more likely to engage with the message (Spence, 1978; Stiglitz, 2000). Hence, an online corporate social media campaign can raise awareness about a firm's societal cause and drive consumer engagement with the message.

Along with creative digital strategies to engage consumers, new forms of marketing approaches are similarly developing and include, systems thinking, multilevel approaches, and up/stream ecological systems (Domegan et al., 2016; Hollebeek et al., 2019). Whilst these advances confirm the marketplace is multi-levelled and composite (Vargo and Lusch, 2004), the role of digital technology to facilitate consumer engagement through complex market systems is well recognized (Dibb, 2014; Shawky et al., 2019).

Online health and wellbeing service providers, are also using digital technology to facilitate engagement to effect outcomes including weight loss programmes (Parkinson, Schuster, Mulcahy, and Taiminen, 2017), sexual health awareness (Mo and Coulson, 2008), 
and breast cancer (Han et al., 2008). Categorized as vulnerable, these consumers are turning to online service providers to receive social support in a safe space that digital technology allows. However, it should be noted these online service providers were community groups and local level health service arrangements. Conversely, there is scant evidence in the literature of a brand engaging vulnerable consumers within a health and wellbeing context. Therefore, we posit the suitability of a brand's corporate social media strategy to engage multiple vulnerable consumers in a health and wellbeing context is boundary breaking.

The meso environment is the setting between the macro (government and institutions) and micro (individual) level, and includes a firm's infrastructure and the goods and services offered to engage consumers. New technologies offer potential meso level opportunities for brands to create value with consumers in more profound ways, empowering consumers who can connect, share and collaborate. Sending signals and evaluating the response from receivers was originally researched by Spence (1978). This seminal work found that in circumstances where a firm's message signals something of importance to the receiver, an enhanced connection can develop. Therefore, with the correct corporate message content and advancements in digital technology, marketers can interact with customers and strategize consumer engagement activities (Belk, 2009; Hollebeek et al., 2014; Hollebeek, 2018; Kannan, 2017; Lee, Hosanagar, and Nair, 2018; Llamas and Belk, 2013). The near ubiquity of mobile phones has created an on-going demand to understand how consumers engage with brands on social media (Brodie et al., 2013; Kubacki and Szablewska, 2017; Muller and Peres, 2019). For example, the growth of social platforms has led to a rise in brands' involvement in corporate philanthropy when a social issue is not sufficiently tackled by macro level institutions (Kotler, Hessekiel, and Lee, 2012; Zdravkovic et al., 2010). 


\subsection{Vulnerable Consumers}

Vulnerability can change according to a consumer's circumstances or market context. For instance, some groups can be made vulnerable by embedded societal norms and values in both developed and developing economies (e.g. a combination of bankruptcy and effects of ill health, respectively) (Alexander et al., 2018). Other consumers may be vulnerable because of situation- specific physical or sensory disability (Baker, Gentry, and Rittenburg, 2005).

In general, consumers who do not conform to an idealised body shape, size or appearance face challenges in being accepted and experience stigmatisation (Harju and Huovinen, 2015; Sandikici and Ger, 2009). While some consumers have the confidence to contest these challenges by embracing the differences in their appearance, others are less able to do so (Belk, 1988). Furthermore, the diagnosis of a life-threatening illness may mean consumers feel unable to contest such challenges and as a result are left marginalised and vulnerable (Mason and Pavia, 1998).

The emergence of new marketing paradigms such as service-dominant logic represents a shift from the traditional market exchange of goods (Lefebvre, 2012). The provision of knowledge and skills (operant and operand resources) for consumer health and wellbeing means the firm operates from a transformative service perspective. For example, Unilever introduced "soapchalk" to educate vulnerable children in community schools in India about personal hygiene. Similarly, Whirlpool introduced 'Care Counts Laundry' programme in schools in USA for vulnerable students (Fill and Turnbull, 2019).

In the context of breast cancer, especially as the illness involves both threat to life and disfigurement, the physical transformation of the body often leaves women with feelings of dissonance (Pounders and Mason, 2018). Women typically experience stress, negative impact on self-image and poor confidence. This creates disruption to social, professional and 
personal life and, frequently leaves women unclear about their long-term survival. The access to resources to assist with the physical and emotional effects of the illness and adapt to the new way of life is essential.

In Western markets the cumulative impact of family and friends, the healthcare professional's expertise and rehabilitation support services have been found to help breast cancer sufferers' physical and emotional wellbeing (Martins et al., 2019). Mason and Pavia's (1998) study in the USA reviewed the array of resources available to women such as, medical information, access to support groups, cancer workshops and rehabilitation advice. However, the authors stressed their findings are not representative of the effect of breast cancer on vulnerable consumers in non-Western contexts. Women in less developed countries are less likely to be emancipated or empowered to take action and are unaware of how or where to access help. This usually results in social stigma and exclusion. Specifically, in these market contexts, which are bound by cultural norms and constrained by weak public health support, a complex and seemingly unresolvable situation may persist.

There has been some health research into emotional and social support to reduce stigma, blame, shared experience and social inclusion (McCormack, 2010; Martins et al., 2019). Vulnerable consumers who are socially excluded through stigmatisation may look for support from non-medical institutions operating online transformative service support (Aboud and Singla, 2012; McCormack, 2010; Na and Na, 2013; Ostrom et al., 2010; Yao et al., 2015). For example, by searching for support online, the fear of stigmatisation is reduced, since counselling or advisory resources can be accessed without their appearance being judged.

\section{The Selected Case: Dabur Vatika's Hair Loss Social Media Campaign}




\subsection{India's cancer crisis}

In India, 2,000 women per day are diagnosed with cancer and by the end of 2020, 2.5 million Indian women will be living with breast cancer (WHO, 2016). This critical situation arises from structural drivers at macro level which include a lack of political resolve to invest in primary healthcare services for women (Alexander et al., 2018). This is unusual because macro institutions can affect social norms that are detrimental to segments of society if they so wish. The introduction of legislation to improve civil, gender and religious rights has been found to have some positive influence on stigmatized situations (Bloom, 2019). Eventual acceptance by society of situations that render individuals vulnerable (including stigma and disfigurement) can galvanise support for greater social inclusion. Furthermore, legislation can move reluctant members of society to gradually adapt to the new situation. For example, a mandatory breast screening health policy introduced by the Australian government found that co-creating pre-screening activities facilitated greater uptake by those women fearful of the process (Davey et al., 2019). However, in India the resourcing of cancer care remains poor.

While international standards suggest a minimum of 25 health workers per 10,000 population, a lack of fiscal investment by India's government results in only 8 health workers per 10,000 population (Srinivasan and Chandwani, 2014). Such low numbers of qualified health staff impacts on the accessibility and quality of service provision and resources. Western countries for example provide cancer support resources, such as physiotherapy, wig makers, community cancer nurses and cancer counsellors. These are rare resources in India (Cope with cancer, 2015). The scarcity of resources is compounded by the stigma attached to hair loss. The deep-rooted connection between Indian women and long hair as a representation of beauty is entrenched in mythology, culture, childhood rituals, cinema and haircare advertising (Kulke and Rothermund, 2016; Mendes, 2015). Women view their hair as a religious identity and a symbol of their cultural status (Kaur, 2013) and as such, hair loss 
associated with chemotherapy has become stigmatised (Barg and Grier, 2008; Harfmann and Bechtel, 2015).

\subsection{The corporate social media campaign}

Dabur Vatika is a leading international brand in emerging markets with a US\$7 billion market capitalisation and a presence in the Asian hair care market (Dabur Vatika, 2019). In recognition of their philanthropic ideology on health and wellbeing they were awarded the 'Global Retailer of the Year' award during the Middle East Asia Leadership Summit and Awards 2017 (Dabur International wins top award, 2017).

A customer research study revealed deep insight into the importance of hair in an Indian woman's life, and highlighted many were willing to choose saving their hair over lifesaving chemotherapy treatment (WARC, 2019). Given the paucity of information and support to breast cancer sufferers in India, Dabur Vatika decided to change the hair and beauty conversation to stand by women who were fighting cancer. A single film was created to embody their 'you do not need hair to be beautiful' point of view (see Appendix 1). The campaign was curated with the knowledge that normative social behavior dictates Indian women should not disclose private issues about their bodies (Fletcher-Brown, 2020). The objective was therefore, to mobilise a network to support vulnerable women suffering from cancer, through the anonymity of online engagement with the social media message. No other haircare brand had previously offered a voice or support to marginalised women fighting cancer.

Dabur Vatika responded to the comments posted online for more than a five year period after posting the video campaign. Respondents were invited to contribute with their own stories via the website which resulted in Principal Vulnerable Consumers and Associate 
Vulnerable Consumers sharing experiences about hair loss from cancer. The brand continued publishing these accounts across touchpoints, TV, newspapers, radio, social media, brand website, digital video, display ads, PR, packaging and celebrity events.

\section{Research Design}

To explore VCE with computer-mediated communications and to allow for original theoretical explanations to emerge from the data, we adopted a three-stage protocol aligned to Belk and Sobh (2019). From the outset of this study, the researchers sought to gain novel insight about the phenomena under investigation and cultivate new theory. To do this, we combined a grounded theory and abductive reasoning approach to generate alternative theoretical explanations (Belk and Sobh, 2019).

Such qualitative approaches are valuable in understanding consumers' hidden motives surrounding their reaction to advertising messages and provide rich insight into the emotional motivations of consumers towards a brand message (Belk, 2017; Nuttall et al., 2011). Similar approaches have been used in a range of health advertising studies (Gonzalez et al., 2008; Wiesenfeld, Bush, and Sikdar, 2010).

The study adopted the recommended netnography protocol of Kozinets (2019). Netnography is a qualitative research methodology that adapts ethnographic research techniques to study cultures and communities that are emerging through computer-mediated communications. Netnography allows data to be collected in an entirely unobtrusive fashion from a hard-to-reach demographic, such as Indian women with cancer (see Fletcher-Brown, 2020). Online forums therefore provide useful access to people who have self-segmented by a certain type of lifestyle (in this instance health and wellbeing) which researchers can translate into private (one-to-one) online real time interviews (Hamman, 2007). 


\subsection{Sample and data collection}

The qualitative data collected for this study was based on $n=634$ comments posted in English on YouTube in response to Dabur Vatika's \#BRAVEANDBEAUTIFUL campaign, which was initially uploaded on December 31, 2014 (see Appendix 1). At the time of this investigation the video had received more than 5 million views, over 1 million shares, as well as 1 billion impressions across different platforms (WARC, 2019). Social media messages were analysed over a five-year period to explore consumers' cognitive, emotional and behavioral engagement with the brand's message. During this time span we did not observe any critical incidents or consumer cycles.

To begin with, the researchers transcribed all the comments from the YouTube site. Next, following the process adopted by Kozinets (1998) the online commenters were categorise into sub-groups. This provided the most insightful data. We distinguished two distinct vulnerable consumer groups, Principal Vulnerable Consumers and Associate Vulnerable Consumers. Adopting these classifications enabled us to identify those commenters who were close to the phenomena under investigation.

\subsection{Coding Procedure}

The data was analysed using a three-tiered coding system following the Gioia method (Gioia et al., 2013). In the first stage of the analysis the researchers independently read and coded the online comments. These comments were organised manually into a set of 1st- order concepts; Destigmatisation; Support network ; Sharing experiences; Expressions of renewed 
strength; Prescriptive advice; Advice on collateral issues and Advice on alternative pathways.

The second stage, involved a $2^{\text {nd }}$ - order analysis whereby the researchers sought to understand links between the data and new concepts. This 'sensegiving' provided an opportunity for concept development and theory building (Gioia and Chittipeddi, 1991). In the third stage, the researchers aggregated key themes to provide a set of summative dimensions to the data (see Table 1). In contrast to other methods for analysis, such as content analysis, the use of the Gioia method approach allowed for alternative theoretical explanations to emerge from the data and has been used effectively to understand phenomenon in other health care studies (see Furstenau and Auschr, 2016; Schölmerich et al., 2016). Finally, following Wallendorf and Belk (1989), an inter coder agreement to endorse the coding scheme revealed a $94 \%$ overlap between the two coders $(n=596)$. The coders discussed the remaining $6 \%$ of data $(n=38)$ and an agreement was reached.

\section{Findings}

To be able to understand the nature of VCE, we present our analysis of the responses to the selected brand's social media campaign. This allows us to understand the benefits a meso level corporate social media campaign, can provide to vulnerable consumers. Based on the coding structure presented above, three key themes emerge from the data:

Theme 1: Support for Principal Vulnerable Consumers,

Theme 2: Support for Associate Vulnerable Consumers and,

Theme 3: A knowledge hub for Principal Vulnerable Consumers and Associate Vulnerable Consumers.

Theme 1 includes posted comments from Principal Vulnerable Consumers with first-hand experience of the stigma of losing hair. Theme 2 comprises of posted comments from the 
Associates and Theme 3 posted comments from both Principal Vulnerable Consumers and Associate Vulnerable Consumers. To offer a better understanding of the findings, an extract of data to illustrate each theme is presented in Table 1.

\section{[Insert Table here]}

\section{Theme 1: Support for Principal Vulnerable Consumers}

From the collected data two subthemes emerged from the Principal Vulnerable Consumer group's comments: Destigmatisation and Support network (see Table 1) to indicate two areas of resource depletion. Destigmatisation resource includes links to personal blogs and stories about coping with stigma. Support Network resource assists with side effects of hair loss, including poor mental-health and lack of self-confidence. One Principal Vulnerable Consumer posted, "Thanks for this platform where for [the] first time I am able to express myself about this issue. I have grown my hair back". This comment was posted three years into the campaign, which demonstrates the community network was still a relevant resource. The Principal Vulnerable Consumers' experiences of isolation through stigma were communicated; "I have been there, blaming and snickering [about hair loss] makes it tough" and, "The crux of the matter is to accept [us] the people who are "different" from the standard norms of beauty”. Many expressed the difficulty to articulate their emotions, living with cancer and the fear of stigma, "lost confidence after all the chemo \& radiation therapies. I didn't talk to anyone... and now I read here about others [hair loss] and [now] I have the courage to fight against the frightening".

Many used the community group to unburden themselves, “@Dabur MyBeautyNaturally Hi, I would like to share my experience”. The technology facilitated an unprecedented intimacy with the Principal Vulnerable Consumers to disclose their private 
stories which contributed to the discourse, "Where can I share my story? Directly posting on your FB page?". The reach of the online network as a health and wellbeing resource extended to Principal Vulnerable Consumers from alternative vulnerable consumer groups experiencing stigma, which was unexpected, "Glad to see this video by Dabur. Could relate to Guillain Barrieh Syndrome. My beauty still lies in my smile".

Although the direction of the conversation is non-linear, VCE is maintained through the consistency of the brand's communication signal which encourages vulnerable women to contribute their story or offer support to others. Respondents can drop in and out of the message thread at any point in the discourse continuum. The comments serve as a sustainable resource to encourage solidarity to fight social stigma. The technology therefore, facilitates a service-centered position for the brand, which is inherently consumer-oriented and has potential to impact positively on the quality-of-life of vulnerable women.

At meso level the brands' corporate social media acts to replenish resources that usually emanate from macro institutions, in an emerging country context. The continued sharing of empathetic individual personal narratives of stigma, evolved to form a community support network where scant existed previously, "We don't need hair to look beautiful we are survivors". The brand responded to acknowledge the Principal Vulnerable Consumers' engagement with the message and offered encouragement, "Do let us know if you know someone who survived cancer bravely and beautifully, we want to capture these brave stories \& bring them as heroes. We need your help!". In other words, the notion of "meso" in this study fills the gap between micro and macro levels and contributes to an improved understanding of VCE. The replenishment of resources for Principal Vulnerable Consumers, emerges at micro level, evidenced by their cognitive, emotional and behavioral engagement with the campaign. 


\section{Theme 2: Support for Associate Vulnerable Consumers}

Knowing others have faced and overcome similar obstacles can provide relief through shared experience, offering renewed encouragement for the individual (Martins et al., 2019). Theme 2 includes two subthemes that emerge from the Associate Vulnerable Consumers' comments: Sharing experiences and Expressions of renewed strength to indicate two areas of resource depletion (see Table 1). The first, Sharing experiences resource, includes accounts from those who have witnessed the side effects of chemotherapy. The second, Expressions of renewed strength resource includes statements of encouragement to Associates Vulnerable Consumers to keep them strong whilst they support Principal Vulnerable Consumers.

The Associate Vulnerable Consumers are distinguished from the Principal Vulnerable Consumers group by their proximity to the challenges of cancer. For example, a genetic or family connection that heightens their interest or a societal connection through friendship or employment. This afforded the Associate Vulnerable Consumers to engage with selective elements of the discussion that were relevant to their own resource constraint. For example, unburdening the emotional weight of nursing a loved one, "It's difficult seeing my mother without hair but I must be brave” and, “"I know the stress of baldness from cancer ...I shampoo my girlfriend's head to help her because she is tired .... Seeing her smile helps me to be strong for her", or supplying comfort through empathy, "This is real I know because my mother has cancer".

The computer-mediated communications created an engagement network, developed through interpersonal operant resources. The network operates as an emotional resource for Associate Vulnerable Consumers to share experiences and show support that generates renewed encouragement, "the gruelling chemo sessions, the fact that mother looks different" 
and, "My mom has breast cancer; she lost her hair through chemo. I used her hair to learn to walk. She gave me the scissors to cut off her hair imagine my pain”. The Associate Vulnerable Consumers share how they showed acts of caring, "I now donate my cut hair for cancer wigs" and, "extend words of positive confidence in people who are battling their lives to survive" cultivated the co-creation of an emotional resource. Therefore, our findings show that Associate Vulnerable Consumers also suffer from resource depletion, which is fulfilled by the community network.

\section{Theme 3: A knowledge hub for Principal and Associate vulnerable consumers.}

Social engagement relates to the degree to which audiences are intellectually and voluntarily motivated to become involved in the message (Hollebeek, 2018). Furthermore, in digital online health and wellbeing (qualitative) research, the scale of social support as a resource can be assumed by the degree of user satisfaction (Anson, Stanwyk and Krause, 1993). In this study we illustrate the value of the resource as a knowledge hub, created through the online socialization of the Principal Vulnerable Consumers and Associate Vulnerable Consumers about issues to do with cancer.

Three subthemes emerged to illustrate depleted resources; Prescriptive advice, Advice on collateral issues and Advice on alternative pathways. The first Prescriptive advice resource includes information such as preferred medical consultants and how chemotherapy works. Advice on collateral issues resource consists of information about diet and skincare products suitable for chemotherapy patients. Advice on alternative pathways forms a resource about complimentary medicine such as positive mental thinking and holistic treatments. 
A wealth of individual knowledge was shared among the community, "If you have completed your therapies you must follow up as your doctor said", and, "Try Ayurvedic medicine to boost immunity power". Principal Vulnerable Consumers also recommend consultants to help peers in similar conditions, "I recently had my treatment ... thanks to Dr. @. YYY hospital”. VCE in this wellbeing context is shaping a cognitive, emotional and behavioral response through co-creation of a valued resource which provides knowledge and advice. Others asked the community direct questions about diet and recommended treatments for remission, "I'm a cancer survivor. Can anyone tell me what to eat and what not to"? and, "recovery is possible by confidence and good mental state rather than medicine", asserting the usefulness of alternative therapies and a positive mind-set.

The interactional nature of the digital platform allowed the sharing of knowledge and experiences with cancer, forming a valuable resource. The vulnerable consumer's co-creation of value is evident in the disclosure of relevant information about diet and alternative therapies, which evolved as a process of socialization about matters concerned with cancer.

\section{Discussion and Conclusion}

Using an abductive reasoning approach, we have engaged in boundary breaking work to enhance understanding about marketing's influence for the social good of vulnerable consumers. Specifically, in an emerging country context, where provision of health and wellbeing resources are limited, Principal Vulnerable Consumers and Associate Vulnerable Consumers are willing to engage with corporate social media to destigmatise hair loss to create online support and a knowledge hub. This identifies the power of the meso level marketing environment to intervene and transform the health and wellbeing of vulnerable consumers where at macro level there is scant support. 
This study highlights how corporate social media can facilitate resources for vulnerable consumers. First, resources can support Destigmatisation and provide a Support network. Second, Sharing experiences and Showing renewed strength act as a resource to support consumers. Third, the co-creation of A knowledge hub provides; Prescriptive advice, Advice on collateral issues and Advice on alternative pathways. This boundary-breaking research was inspired by a real-world phenomenon, and vulnerable demographic that has received little attention to date (MacInnes et al., 2019). Drawing on consumer engagement literature which highlights how value can be generated among stakeholders (Brodie et al., 2011; Vargo and Lusch, 2004; 2017), we examine engagement between actors in a vulnerable context. This study identifies a nascent form of engagement, which has been derived from the understanding of how vulnerable consumers engage. We recognise this as Vulnerable Consumer Engagement and offer a preliminary definition as follows, "the level of replenishment of depleted cognitive, emotional, behavioral and social resources invested by vulnerable individuals with scant operant resources".

Our findings offer insights for the conceptualization of VCE and illustrate the power of the meso level environment to fill the resource void in contexts of poor macro level support service provision (Wallack et al., 1993; Wymer, 2011). The level of perceived value of the resource is observed from the interaction of the Principal Vulnerable Consumers and Associate Vulnerable Consumers who create value through individual pro-active contributions about personalised experiences of coping with hair loss through cancer during this time (Belk, 2009; Llamas and Belk, 2013; Vargo and Lusch, 2004, 2016; Verhoef et al., 2016).

The nature of engagement by Principal Vulnerable Consumers and Associate Vulnerable Consumers at micro level illustrates the co-creation of a resource that alleviates social stigma and provides cognitive, emotional and behavioral support. In particular, the 
knowledge hub educates Principal Vulnerable Consumers and Associate Vulnerable

Consumers about the disease, explains some of the symptoms of cancer and the importance of completing the course of prescribed medicine. Therefore, in a societal context where female cancer is rarely discussed, the corporate social media functions to replenish depleted operant resources (Hollebeek et al., 2019).

The support resources and knowledge hub is still active and co-created after five years of its inception, as vulnerable consumers continue to engage with the resources to enhance their health and wellbeing. The nature of engagement with the resources is not momentary, but enduring. This illustrates how VCE is a process of co-created replenishment of resources that has long lasting effects.

In addition to identifying the nature of VCE, the study adds to the advertising literature regarding the length of engagement with corporate social media campaigns. Most advertising campaigns incur 'wear-out', whereby the effects of the message peak and then fade. In contrast, the VCE with \#BRAVEANDBEAUTIFUL campaign, has no sign of traditional advertising 'wear-out' (Chen et al., 2016). We found the effect of advertising was one of volitional resource investment, or 'wear-in'. A brand rarely interacts with consumers past the initial advertising message and, therefore, such longevity of VCE is an unexpected outcome, and a meaningful contribution to advertising and consumer engagement literature.

\subsection{Theoretical Contributions}

We assessed the outcomes of this study in an evaluative way which allowed the researchers to map the phenomenon of VCE with a corporate social media campaign. In so doing, our work offers three clear theoretical contributions. First, we offer a preliminary conceptual structure (Figure 1) which highlights how at meso level a brand can initiate 
engagement with vulnerable consumers to create resources to support them. The framework assists to conceptualize VCE theoretically and illustrates how VCE can be interpreted as social inclusion, rather than exclusion as corporate social media facilitates interpersonal connections with others. Consequently, the ongoing engagement creates supportive resources which are valuable for vulnerable consumers at times of health and wellbeing crisis.

Second, the study has identified two distinct and generalizable vulnerable consumer groups: Principal Vulnerable Consumers and Associate Vulnerable Consumers. They are delineated by their proximity to the phenomena investigated, which is important for our understanding about the differences in their nature of engagement with the \#BRAVEANDBEAUTIFUL. Following the call from Pavia and Mason (2014) to analyze different layers of vulnerability, we encourage others to further explore these two consumer groups in different ground breaking consumer behavior research studies.

Third, the causality of the depleted resources in this study is shaped by structural drivers at macro level, mainly a lack of political resolve to invest in women's primary health care services and the social stigma attached to hair loss from cancer. We illustrate how a brand may perform a transformative role, in an age of technology-dominated communications to successfully replenish depleted social, emotional and operant resources at micro level through the engagement of vulnerable consumers with corporate social media.

\section{[Insert Figure 1 here]}

Our study challenges Wymers's (2011) assumption that macro level actors will provide consumers with health and wellbeing resources. In contrast, we show how at meso level a brand's corporate social media campaign engages vulnerable consumers at micro level to provide support resources. The brand can therefore unite vulnerable consumers in a 'winwin' situation that benefits all parties with a successful transformative marketing strategy. 


\subsection{Practical contributions}

Understanding more about the nature of consumer engagement with corporate social media provides opportunities for brands to develop future campaigns to support other vulnerable consumers. This may align with an organisation's wider corporate social responsibility objectives. In particular, in contexts where consumers have limited operant resources, brands are able to provide transformative services (Anderson et al., 2013; Hollebeek et al., 2019) to improve wellbeing of vulnerable consumers. For example, brands may wish to consider how they can support cancer patients and other vulnerable consumers in emerging countries.

While some brands have chosen corporate social media campaigns to address some of societies key challenges, such as stereotyping of women in advertising (Middleton, Turnbull, and de Oliveira, 2019), this study highlights how brands could similarly address health and wellbeing issues. Brands could play a significant role in addressing stigma, for instance stigma attached to illnesses that impacts on body image with a market led campaign.

Our study also provides rich insights for corporate social media strategists. When designing content for campaigns, both Principal Vulnerable Consumer and Associate Vulnerable Consumer audiences need to be considered. For example, recognising how different vulnerable consumers engage with messages may allow for targeted narrative content development.

Finally, practitioners have begun appraising VCE as one of the most important marketing approaches to address societal challenges in consumer markets (Accan, 2020). However, both research and practice lack a clear understanding, demarcation and generalisation of this concept. We systemise and describe this concept by integrating recent theoretical marketing research and relevant empirical evidence. Therefore, the study contributes to establishing an accepted VCE conceptualisation. 


\subsection{Future Research Agenda}

The current research is exploratory in nature and hence has limitations in terms of generalisability. However, the study provides a novel theoretical contribution to knowledge about VCE and the findings open up a rich research agenda. One suggestion is to investigate whether such campaigns drive behavioral change. For instance, by measuring whether women did continue with their chemotherapy in a controlled longitudinal field study.

It would also be fruitful to examine the specific differences between $\mathrm{CE}$ and VCE to extend our understanding of the nature of VCE. For example, it would be of interest to understand more about VCE in contexts of different levels of stigmatization that result from disease or other social causes.

Additionally, it would be important to assess possible changes in brand perception as a result of the campaign. In the investigated case, the financial performance of Dabur Vatika improved more than $20 \%$ over the investigated period, both in terms of sales and profit (Thakur, 2019). While brand perceptions were likely enhanced, these results might be explained by several other factors that can be ruled out with a field experiment.

Furthermore, the framework could be explored in Western countries with more informed actors and higher levels of macro interventions. For example, where vulnerable consumers have been investigated in Western contexts previously (Pavia and Mason, 2014) and supportive resources are generally in place, we would not expect that a similar meso environment strategy would activate such a significant effect on vulnerable consumer engagement.

We offer VCE as a pioneering concept for discussion and further validation. For example, this conceptualization could be used to examine how brands and corporate social media facilitate vulnerable consumers' access to resources during the COVID-19 crisis. 
Specifically, how to avoid panic buying of food and poor market arrangements to supply medical resources.

\section{References}

Aboud, F. E., \& Singla, D. R. (2012). Challenges to changing health behaviors in developing countries: a critical overview. Social science \& medicine, 75(4), 589-594.

Accan.org.au. (2020). [online] Available at:

https://accan.org.au/Breaking\%20Down\%20Barriers\%20to\%20Digital\%20Governme nt.pdf [Accessed 18 Feb. 2020].

Alexander, A., Kaluve, R., Prabhu, J.S., Korlimarla, A., Srinath, B.S., Manjunath, S., Patil, S., Gopinath, K.S., \& Sridhar, T.S. (2018). Treatment decision making, and strategies for coping with financial stress in Indian women diagnosed with breast cancer and their families. Cancer Research, 78(4).

Anderson, L., Ostrom, A.L., Corus, C., Fisk, R.P., Gallan, A.S., Giraldo, M., Mende, M., Mulder, M., Rayburn, S.W., Rosenbaum, M.S., \& Shirahada, K. (2013). Transformative service research: An agenda for the future. Journal of Business Research, 66(8), 1203-1210.

Anson, C. A., Stanwyck, D. J., \& Krause, J. S. (1993). Social support and health status in spinal cord injury. Spinal Cord, 31(10), 632.

Baker, S. M., Gentry, J. W., \& Rittenburg, T. L. (2005). Building understanding of the domain of consumer vulnerability. Journal of Macromarketing, 25(2), 128-139.

Barg, F. K., \& Grier, S. A. (2008). Enhancing breast cancer communications: A cultural models approach. International Journal of Research in Marketing, 25(4), 335-342. 
Belk, R. W. (1988). Possessions and the extended self. Journal of Consumer Research, 15(2), 139-168.

Belk, R., (2009). Sharing. Journal of Consumer Research, 36(5), 715-734.

Belk, R. W. (2017). Qualitative research in advertising. Journal of Advertising, 46(1), 36-47.

Belk, R., \& Sobh, R. (2018). No assemblage required: On pursuing original consumer culture theory. Marketing theory, 19(4), 489-507.

Bloom, J. M. (2019). Class, race, and the civil rights movement, Bloomington Indiana: University Press:

Brennan, L., Zevallos, Z., \& Binney, W. (2011). Vulnerable consumers and debt: Can social marketing assist?. Australasian Marketing Journal (AMJ), 19(3), 203-211.

Brodie, R. J., Hollebeek, L. D., Jurić, B., \& Ilić, A. (2011). Customer engagement: Conceptual domain, fundamental propositions, and implications for research. Journal of Service Research, 14(3), 252-271.

Brodie, R. J., Ilic, A., Juric, B., \& Hollebeek, L. (2013). Consumer engagement in a virtual brand community: An exploratory analysis. Journal of Business Research, 66(1), 105114.

Chen, T., Dodds, S., Finsterwalder, J., Witell, L., Cheung, L., Falter, M., Garry, T., Snyder, H., \& McColl-Kennedy, J. (Forthcoming). Dynamics of Wellbeing Co-Creation: A Psychological Ownership Perspective, Journal of Service Management, 1-51.

Chen, J., Yang, X., \& Smith, R. E. (2016). The effects of creativity on advertising wear-in and wear-out. Journal of the Academy of Marketing Science, 44(3), 334-349.

Coping with Cancer (2015). Cancer Counselling in India. Retrieved 24 January 2020, from https://www.copewithcancer.org/copewithcancer-archives/cancer-counselling-india

Dabur International wins top award (2017). Tradearabia, April 2.

Retrieved from http://www.tradearabia.com/news/IND_322756.html. 
Dabur Vatika (2019). Retrieved from Error! Hyperlink reference not valid., 14 August 2019.

Davey, J., Herbst, J., Johns, R., Parkinson, J., Russell-Bennett, R., \& Zainuddin, N. (2019). The role of health locus of control in value co-creation for standardized screening services. Journal of Service Theory and Practice, 30(1), 31-55.

Dibb, S. (2014). Up, up and away: social marketing breaks free. Journal of Marketing Management, 30(11-12), 1159-1185.

Dietrich, T., Trischler, J., Schuster, L., \& Rundle-Thiele, S. (2017). Co-designing services with vulnerable consumers. Journal of Service Theory and Practice, 27(3), 663-688.

Domegan, C., McHugh, P., Devaney, M., Duane, S., Hogan, M., Broome, B.J., Layton, R.A., Joyce, J., Mazzonetto, M., \& Piwowarczyk, J. (2016). Systems-thinking social marketing: conceptual extensions and empirical investigations. Journal of Marketing Management, 32(11-12), 1123-1144.

Fill, C., \& Turnbull, S. (2019). Marketing Communications: touchpoints, sharing and disruption. Pearson: Harlow.

Fletcher-Brown, J. (2020). Reflexivity and the challenges of collecting sensitive data in India: a research note. Qualitative Research, 20(1), 108-118. .

Fletcher-Brown, J., Pereira, V., \& Nyadzayo, M. W. (2018). Health marketing in an emerging market: The critical role of signaling theory in breast cancer awareness. Journal of Business Research, 86, 416-434.

Frow, P., McColl-Kennedy, J. R., \& Payne, A. (2016). Co-creation practices: Their role in shaping a health care ecosystem. Industrial Marketing Management, 56, 24-39.

Furstenau, D., \& Auschra, C. (2016). Open digital platforms in health care: Implementation and scaling strategies. [online] Available at: 
https://aisel.aisnet.org/icis2016/ISHealthcare/Presentations/19/ [Accessed 18 Feb. 2020].

Gelband, H., Sankaranarayanan, R., Gauvreau, C.L., Horton, S., Anderson, B.O., Bray, F., Cleary, J., Dare, A.J., Denny, L., Gospodarowicz, M.K., \& Gupta, S. (2016). Costs, affordability, and feasibility of an essential package of cancer control interventions in low-income and middle-income countries: key messages from Disease Control Priorities. The Lancet, 387(10033), 2133-2144.

Gensler, S., Völckner, F., Liu-Thompkins, Y., \& Wiertz, C. (2013). Managing brands in the social media environment. Journal of Interactive Marketing, 27(4), 242-256.

Gioia, D. A., \& Chittipeddi, K. (1991). Sensemaking and sensegiving in strategic change initiation. Strategic Management Journal, 12(6), 433-448.

Gioia, D. A., Corley, K. G., \& Hamilton, A. L. (2013). Seeking qualitative rigor in inductive research: Notes on the Gioia methodology. Organizational Research Methods, 16(1), $15-31$.

Gonzalez, J. S., Peyrot, M., McCarl, L. A., Collins, E. M., Serpa, L., Mimiaga, M. J., \& Safren, S. A. (2008). Depression and diabetes treatment non adherence: a metaanalysis. Diabetes care, 31(12), 2398-2403.

Hamman, R. (2007). Cyborgasms: Ten years on and not enough learned. In Online Matchmaking (pp.31-39). Palgrave Macmillan: London.

Han, J. Y., Shaw, B. R., Hawkins, R. P., Pingree, S., McTavish, F., \& Gustafson, D. H. (2008). Expressing positive emotions within online support groups by women with breast cancer. Journal of Health Psychology, 13(8), 1002-1007.

Harfmann, K.L., \& Bechtel, M.A. (2015). Hair loss in women. Clinical Obstetrics and Gynecology, 58(1), 185-199. 
Harju, A. A., \& Huovinen, A. (2015). Fashionably voluptuous: normative femininity and resistant performative tactics in fatshion blogs. Journal of Marketing Management, 31(15-16), 1602-1625.

Hollebeek, L.D. (2011). Exploring customer brand engagement: definition and themes. Journal of Strategic Marketing, 19(7), 555-573.

Hollebeek, L.D. (2018). Individual-level cultural consumer engagement styles: Conceptualization, propositions and implications. International Marketing Review, 35(1), 42-71.

Hollebeek, L., \& Chen, T. (2014). Exploring positively-versus negatively-valenced brand engagement: a conceptual model. Journal of Product \& Brand Management, 23(1), 6274.

Hollebeek, L.D., Glynn, M.S., \& Brodie, R.J. (2014). Consumer brand engagement in social media: Conceptualization, scale development and validation. Journal of Interactive Marketing, 28(2), 149-165.

Hollebeek, L. D., \& Macky, K. (2019). Digital content marketing's role in fostering consumer engagement, trust, and value: Framework, fundamental propositions, and implications. Journal of Interactive Marketing, 45, 27-41.

Hollebeek, L.D., Srivastava, R.K., \& Chen, T. (2019). SD logic-informed customer engagement: integrative framework, revised fundamental propositions, and application to CRM. Journal of the Academy of Marketing Science, 47(1), 161-185.

IFRC, (2018). What is vulnerability? Retrieved 30 August 2019, from https://www.ifrc.org/en/what-we-do/disaster-management/about-disasters/what-is-adisaster/what-is-vulnerability/

Kannan, P.K. (2017). Digital marketing: A framework, review and research agenda. International Journal of Research in Marketing, 34(1), 22-45. 
Kaur, R. (2013). A Qualitative Study of Hair Loss Among Cancer Patients from Punjab (India). International Journal of Research in Sociology and Social Anthropology, 1(1), 6-10.

Kim, J. E., Lloyd, S., \& Cervellon, M. C. (2016). Narrative-transportation storylines in luxury brand advertising: Motivating consumer engagement. Journal of Business Research, 69(1), 304-313.

Kotler, P., Hessekiel, D., \& Lee, N. (2012). Good works!: Marketing and corporate initiatives that build a better world... and the bottom line. Hoboken New Jersey John Wiley \& Sons.

Kozinets, R. V. (1998). On netnography: Initial reflections on consumer research investigations of cyberculture. ACR North American Advances (25), 366-371.

Kozinets, R. V. (2002). The field behind the screen: Using netnography for marketing research in online communities. Journal of Marketing Research, 39(1), 61-72.

Kozinets, R. V. (2019). Netnography: The Essential Guide to Qualitative Social Media Research. SAGE: London.

Kubacki, K., \& Szablewska, N. (2017). Social marketing targeting Indigenous peoples: a systematic review. Health Promotion International, 34(1), 133-143.

Kulke, H., \& Rothermund, D. (2016). A history of India. Routledge:London.

Leino, H. M. (2017). Secondary but significant: secondary customers' existence, vulnerability and needs in care services. Journal of Services Marketing, 31(7), 760770.

Lee, D., Hosanagar, K., \& Nair, H. S. (2018). Advertising content and consumer engagement on social media: evidence from Facebook. Management Science, 64(11), 5105-5131.

Lefebvre, R.C., 2012. Transformative social marketing: co-creating the social marketing discipline and brand. Journal of Social Marketing, 2(2), 118-129. 
Llamas, R., \& Belk, R. (2013). Living in a digital world. In The Routledge Companion to Digital Consumption (pp. 21-30). Routledge. London.

Loureiro, S. M. C., \& Lopes, J. (2019). How corporate social responsibility initiatives in social media affect awareness and customer engagement. Journal of Promotion Management, 25(3), 419-438.

MacInnis, D. J., Morwitz, V. G., Botti, S., Hoffman, D. L., Kozinets, R. V., Lehmann, D. R., \& Pechmann, C. (2019). Creating Boundary-Breaking, Marketing-Relevant Consumer Research. Journal of Marketing, 84(2),1-23.

McCormack, A. (2010). Individuals with eating disorders and the use of online support groups as a form of social support. CIN: Computers, Informatics, Nursing, 28(1), 1219.

Martins, A., Whelan, J. S., Bennister, L., Fern, L. A., Gerrand, C., Onasanya, M. \& Taylor, R. M. (2019). Qualitative study exploring patients experiences of being diagnosed and living with primary bone cancer in the UK. BMJ open, 9(9), e028693.

Maslowska, E., Malthouse, E. C., \& Collinger, T. (2016). The customer engagement ecosystem. Journal of Marketing Management, 32(5-6), 469-501.

Mason, M., \& Pavia, T. (1998). The disruption of the consumer life cycle by serious illness: the case of breast cancer. ACR North American Advances, (25), 416-420.

Mendes, A. (2015). Indian aesthetics: balancing budgets for Bollywood beauty. Journal of Aesthetic Nursing, 4(5), 238-239.

Middleton, K., Turnbull, S., \& de Oliveira, M. J. (2019). Female role portrayals in Brazilian advertising: are outdated cultural stereotypes preventing change?. International Journal of Advertising, 1-20. 
Mo, P. K., \& Coulson, N. S. (2008). Exploring the communication of social support within virtual communities: a content analysis of messages posted to an online HIV/AIDS support group. Cyberpsychology \& behavior, 11(3), 371-374.

Muller, E., \& Peres, R. (2019). The effect of social networks structure on innovation performance: A review and directions for research. International Journal of Research in Marketing, 36(1), 3-19.

Na, L., \& Na, B. (2013). A revolutionary road: an analysis of persons living with hepatitis B in China. Journal of Health Communication, 18(1), 71-91.

Nuttall, P., Shankar, A., Beverland, M. B., \& Hooper, C. S. (2011). Mapping the unarticulated potential of qualitative research: Stepping out from the shadow of quantitative studies. Journal of Advertising Research, 51(1) 50th Anniversary Supplement), 153-166.

Ostrom, A.L., Bitner, M.J., Brown, S.W., Burkhard, K.A., Goul, M., Smith-Daniels, V., Demirkan, H., \& Rabinovich, E. (2010). Moving forward and making a difference: research priorities for the science of service. Journal of Service Research, 13(1), 4-36.

Parkinson, J., Schuster, L., Mulcahy, R., \& Taiminen, H. M. (2017). Online support for vulnerable consumers: a safe place?. Journal of Services Marketing.31 (4/5), 412-422.

Pavia, T. M., \& Mason, M. J. (2014). Vulnerability and physical, cognitive, and behavioral impairment: Model extensions and open questions. Journal of Macromarketing, 34(4), 471-485.

Pounders, K., \& Mason, M. (2018). Embodiment, Illness, and Gender: The Intersected and Disrupted Identities of Young Women with Breast Cancer. In Consumer Culture Theory, (pp.111-122), Emerald: London.

Sandikci, Ö. \& Ger, G. (2009). Veiling in style: how does a stigmatized practice become fashionable? Journal of Consumer Research, 37(1), 15-36. 
Schölmerich, V. L., Ghorashi, H., Denktaş, S., \& Groenewegen, P. (2016). Caught in the middle? How women deal with conflicting pregnancy-advice from health professionals and their social networks. Midwifery, 35, 62-69.

Shawky, S., Kubacki, K., Dietrich, T., \& Weaven, S. (2019). Using social media to create engagement: a social marketing review. Journal of Social Marketing, 9(2), 204-224.

Spence, M. (1978). Job market signaling. In Uncertainty in economics (pp. 281-306). Academic Press. London.

Srinivasan, V., \& Chandwani, R. (2014). HRM innovations in rapid growth contexts: the healthcare sector in India. The International Journal of Human Resource Management, 25(10), 1505-1525.

Stiglitz, J. E. (2000). The contributions of the economics of information to twentieth century economics. The Quarterly Journal of Economics, 115(4), 1441-1478.

Tafesse, W., \& Wien, A. (2018). Using message strategy to drive consumer behavioral engagement on social media. Journal of Consumer Marketing, (35)3 241-253.

Thakur, S. (2019). A study on financial performance analysis of Dabur India Limited. International Journal of Scientific \& Engineering Research, 10(9), 217-223.

Vargo, S. L., \& Lusch, R. F. (2004). The four service marketing myths: remnants of a goodsbased, manufacturing model. Journal of Service Research, 6(4), 324-335.

Vargo, S. L., \& Lusch, R. F. (2014). Service-dominant logic: What it is, what it is not, what it might be? In The Service-Dominant Logic of Marketing (pp. 61-74). Routledge: London.

Vargo, S. L., \& Lusch, R. F. (2016). Institutions and axioms: an extension and update of service-dominant logic. Journal of the Academy of Marketing Science, 44(1), 5-23.

Vargo, S. L., \& Lusch, R. F. (2017). Service-dominant logic 2025. International Journal of Research in Marketing, 34(1), 46-67. 
Verhoef, P. C., Kooge, E., \& Walk, N. (2016). Creating value with big data analytics: Making smarter marketing decisions. Routledge:London.

Verhoef, P. C., Reinartz, W. J., \& Krafft, M. (2010). Customer engagement as a new perspective in customer management. Journal of Service Research, 13(3), 247-252.

Wallack, L., Dorfman, L., Jernigan, D., \& Themba-Nixon, M. (1993). Media advocacy and public health: Power for prevention. Sage. London

Wallendorf, M., \& Belk, R. W. (1989). Assessing trustworthiness in naturalistic consumer research. ACR Special Volumes.

WARC, (2019). Dabur Vatika: Brave and Beautiful. Retrieved from: https://www.warc.com/content/article/dabur_vatika_brave_and_beautiful/108239.

Wiesenfeld, D., Bush, K., \& Sikdar, R. (2010). The value of listening: heeding the call of the snuggie. Journal of Advertising Research, 50(1), 16-20.

World Health Organisation (2016). World Cancer Day. Retrieved from http://www.searo.who.int/india/topics/cancer/en/.

Wymer, W. (2011). Developing more effective social marketing strategies. Journal of Social Marketing, 1(1), 17-31.

Yao, T., Zheng, Q., \& Fan, X. (2015). The impact of online social support on patients' quality of life and the moderating role of social exclusion. Journal of Service Research, 18(3), 369-383.

Zdravkovic, S., Magnusson, P., \& Stanley, S.M. (2010). Dimensions of fit between a brand and a social cause and their influence on attitudes. International Journal of Research in Marketing, 27(2), 151-160. 
Appendix 1: Dabur Vatika corporate social media campaign

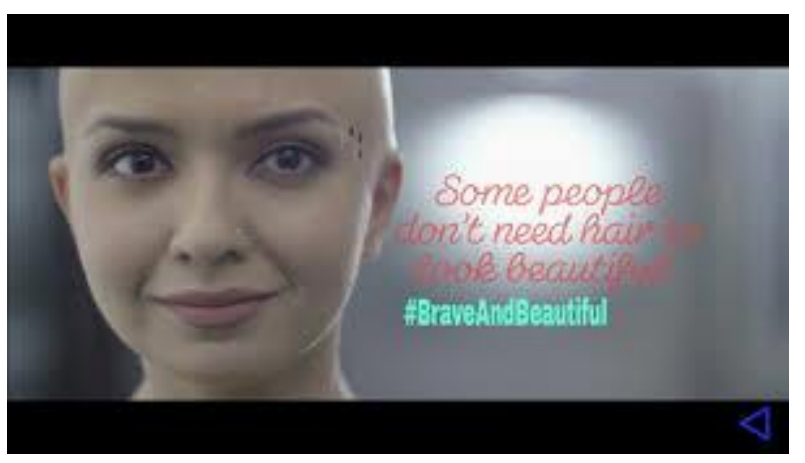

Source: $\underline{\text { https://www.youtube.com/watch?v=LcAbjMXqEPQ }}$ 
Figure 1: How corporate social media engages vulnerable consumers to replenish resources.

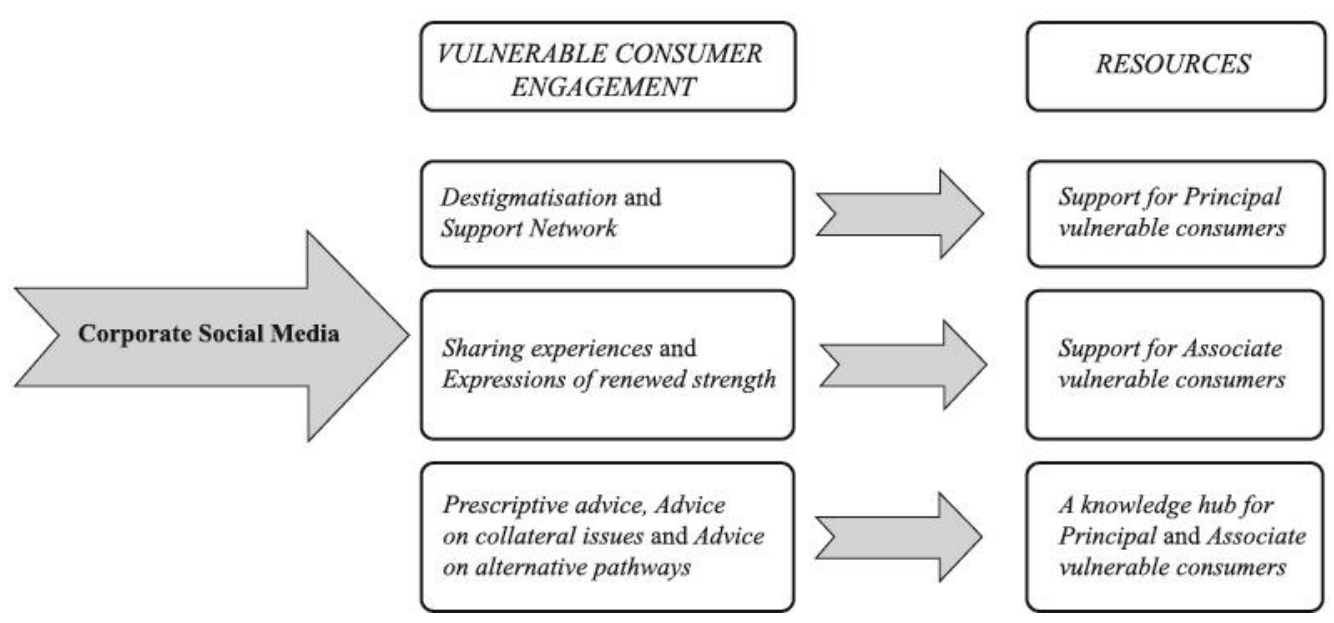


Table 1: Resource themes with illustrative verbatim comments.

\begin{tabular}{|c|c|c|}
\hline Themes & Sub-themes & $\begin{array}{l}\text { Evidence: verbatim comments from } \\
\text { PRINCIPAL respondents [Cognitive] }\end{array}$ \\
\hline \multirow[t]{3}{*}{$\begin{array}{l}\text { Theme } 1 \\
\text { Support for } \\
\text { Principal } \\
\text { vulnerable } \\
\text { consumers }\end{array}$} & Destigmatisation & $\begin{array}{l}\text { "I have been there... The world is not } \\
\text { so nice when you are going through } \\
\text { cancer. Too many personal questions, } \\
\text { blaming and snickering [about hair } \\
\text { loss] makes it tough". }\end{array}$ \\
\hline & & $\begin{array}{l}\text { "The crux of the matter is to accept } \\
\text { [us] the people who are "different" } \\
\text { from the standard norms of beauty and } \\
\text { behaviour". }\end{array}$ \\
\hline & Support network & $\begin{array}{l}\text { "I know I lost confidence after all the } \\
\text { chemo \& radiation therapies. I didn't } \\
\text { talk to anyone... and now I read here } \\
\text { about others [hair loss] and [now] } \\
\text { have courage to fight against the } \\
\text { frightening". }\end{array}$ \\
\hline
\end{tabular}

$\begin{array}{lll}\begin{array}{l}\text { Themes } \\ \text { Theme 2: }\end{array} & \text { Sub-themes } & \begin{array}{l}\text { Evidence: verbatim comments from } \\ \text { ASSOCIATE respondents [Cognitive] }\end{array} \\ \begin{array}{l}\text { Support for } \\ \text { Associate } \\ \text { vulnerable } \\ \text { consumers }\end{array} & \begin{array}{l}\text { Sharing } \\ \text { experiences }\end{array} & \begin{array}{l}\text { "I know the suffering from this } \\ \text { deadly disease... the painful surgery, } \\ \text { the gruelling chemo sessions, the fact } \\ \text { that mother looks different". }\end{array} \\ & \begin{array}{l}\text { Expressions of } \\ \text { renewed } \\ \text { strength }\end{array} & \begin{array}{l}\text { "Falling hairs is one of the side } \\ \text { effects we can't even imagine the pain } \\ \text { it causes during and after the } \\ \text { treatment. Suffering the unbearable } \\ \text { pain from this therapy so we must }\end{array}\end{array}$

Evidence: verbatim comments from PRINCIPAL respondents [Emotional]

"Thanks for this platform where for the first time I am able to express myself about this issue [hair loss]. I have grown my hair back”.

"I am a cancer patient. This video really matters a lot when such a change happens to my life. After my treatment, I joined back in college with a scarf. Those times were hell to me. I lost my self-confidence, but I dared to go".

"Sticks and stones may break my bones but words can never hurt me, remember that next time you get called ugly [from hair loss]!!"”

"I am still on medicine, I have grown my hair back...thanks who helped me and prayed for me in the time of need".

\section{Evidence: verbatim comments from}

ASSOCIATE respondents [Emotional]

"I understand the strain as a son who saw his mother lose her hair to Cancer and herself. This video touch our basic human feelings".

"It's difficult seeing my mother without hair. But I must be brave. Let's all extend words of positive confidence to people who are battling their lives to survive".
Evidence: verbatim comments from PRINCIPAL respondents [Behavioural]

"I have lost my hair and with your care and for an individual like me, I could connect I have been through it".

“@DaburMyBeautyNaturally here is my story http:XXXXblogspot XXX/my-fightagainst-dreadful-disease-cancer.html".

"I am also a cancer patient......please pray for me”.

"We don't need hair to look beautiful, we are surviving".

"Where can I share my story? Directly posting on your FB page?"

\section{Evidence: verbatim comments from} ASSOCIATE respondents [Behavioural]

"My mom has breast cancer; she lost her hair through chemo. I used her hair to learn to walk. She gave me the scissors to cut off her hair imagine my pain. I now donate my cut hair for cancer wigs".

"I know the stress of baldness from cancer ...I shampoo my girlfriend's head to help her

because she is tired .... Seeing her smile helps me to be strong for her". 
support them to continue with the treatment

\begin{tabular}{|c|c|c|c|c|}
\hline \multirow[b]{2}{*}{$\begin{array}{l}\text { Themes } \\
\text { Theme 3: } \\
\text { A } \\
\text { knowledge } \\
\text { hub for } \\
\text { Principal } \\
\text { and } \\
\text { Associate } \\
\text { vulnerable } \\
\text { consumers. }\end{array}$} & \multirow{2}{*}{$\begin{array}{l}\text { Sub-themes } \\
\text { Prescriptive } \\
\text { advice }\end{array}$} & \multicolumn{3}{|c|}{ Evidence: verbatim comments from Principal and Associate respondents } \\
\hline & & $\begin{array}{l}\text { "I recently got my treatment done. I } \\
\text { want to share some knowledge } \\
\text { regarding the diagnosis and how a } \\
\text { wrong decision by one doctor, and } \\
\text { saved by the other thanx to Dr. XXX } \\
\text { @. YYY hospital." Principal. }\end{array}$ & $\begin{array}{l}\text { "If I skip my medicines I will have } \\
\text { delusion and depression again". Principal } \\
\text { "It depends on which stage of cancer } \\
\text { detection for the diagnosis" Associate. }\end{array}$ & $\begin{array}{l}\text { "Did you know Medicine intake during } \\
\text { cancer treatment, damages the cell which } \\
\text { causes hair to fall. But Medicine is very } \\
\text { necessary Try Ayurvedic medicine to boost } \\
\text { immunity power". Associate } \\
\text { "If you have completed your therapies you } \\
\text { must follow up as your doctor said." } \\
\text { Associate. }\end{array}$ \\
\hline & $\begin{array}{l}\text { Advice on } \\
\text { collateral issues }\end{array}$ & $\begin{array}{l}\text { "I'm a cancer survivor. Can anyone } \\
\text { tell me what to eat and what not to?" } \\
\text { Principal. }\end{array}$ & $\begin{array}{l}\text { One of the resource from where I buy } \\
\text { Dabur Ayurveda products (address } \\
\text { supplied)". Principal. }\end{array}$ & $\begin{array}{l}\text { "I generally buy toxin and chemical free } \\
\text { products". Principal }\end{array}$ \\
\hline & $\begin{array}{l}\text { Advice on } \\
\text { alternative } \\
\text { pathways }\end{array}$ & $\begin{array}{l}\text { "I think cancer is such a disease in } \\
\text { which recovery is possible by } \\
\text { confidence and good mental state } \\
\text { rather than medicine". Associate. }\end{array}$ & $\begin{array}{l}\text { "Guidance for CANCER patients \& their } \\
\text { relatives, Adopt Anti - Cancer Diet plan to } \\
\text { not relapse Cancer again. Alternative } \\
\text { Medicinal Therapist (address supplied)". } \\
\text { Associate. }\end{array}$ & $\begin{array}{l}\text { "After your cycle of treatment the cancer cell } \\
\text { would have gone. But keep smiling and } \\
\text { positive attitude it will help you to overcome } \\
\text { cancer". Associate. }\end{array}$ \\
\hline
\end{tabular}

